\title{
Acute Cholecystitis Reduces Interstitial Cells of Cajal in Porcine Gallbladder Through Decreased mRNA Synthesis
}

\author{
Zhen-peng Huang ${ }^{a}$ Hu Qiub,c Bao-ping Yub,c \\ aTeaching and Research Section of Internal Medicine, College of Clinical Medicine, Xi'an Medical \\ University, Xi'an, 'Department of Gastroenterology, Renmin Hospital of Wuhan University, Wuhan, 'Key \\ Laboratory of Hubei Province for Digestive System Diseases, Wuhan, China
}

\section{Key Words}

Interstitial Cajal cells • Acute cholecystitis - Stem cell factor • C-kit • Anti-polymorphonuclear neutrophil

\begin{abstract}
Background/Aims: Acute cholecystitis is a common gastrointestinal disorder, often characterized by acute cholecystitis with gallbladder motility disorder. Interstitial cells of Cajal (ICCs) are the pacemaker cells of gut motility in the gastrointestinal tract. Disruption of ICC function is related to motility disorders. The aim of this study was to explore the cellular and molecular mechanisms of ICCs in acute cholecystitis and after the resolution of acute inflammation. Materials and Methods: Fifty adult guinea pigs were randomly divided into five groups: a sham-administered group (control group); two groups that were intraperitoneally administered an anti-polyclonal neutrophil (PMN) antibody $24 \mathrm{~h}$ before common bile duct ligation (CBDL); and two groups of guinea pigs that were subjected to CBDL without receiving the PMN antibody. Guinea pigs that underwent CBDL were held for $24 \mathrm{~h}$ or $48 \mathrm{~h}$ after surgery before being subjected to laparotomy and cholecystectomy. Immunohistochemistry, TUNEL assays, western blotting, and real-time PCR were performed to determine ICC morphology and density, to detect ICC apoptosis, and to examine stem cell factor (SCF) and c-kit protein expression and SCF and c-kit mRNA levels, respectively. Results: Both hematoxylin-eosin staining and histological inflammation scores in the PMN groups were lower than those in the control groups $(P<0.01)$. No differences were observed in ICC morphology between groups. During acute cholecystitis, ICCs numbers were reduced. Conversely, the density of ICCs increased after inflammation was relieved $(P<0.01)$. In addition, SCF and c-kit protein and mRNA expression levels decreased during acute cholecystitis $(P<0.05)$ and increased after inflammation was relieved $(P<0.05)$. Furthermore, ICC apoptosis increased during acute cholecystitis and decreased after resolution of acute cholecystitis $(P<0.01)$. Conclusions: In acute cholecystitis, ICC injury may be related to gallbladder motility disorder.
\end{abstract}

Hu Qiu and Zhen-peng Huang contributed equally to this work. 


\section{Cellular Physiology Cell Physiol Biochem 2018;47:535-544 and Biochemistry Published online: May 24, $2018 \quad$\begin{tabular}{l|l} 
DOI: 10.1159/000489987 2018 The Author(s). Published by S. Karger AG, Basel \\
www.karger.com/cpb
\end{tabular} \\ Huang et al.: Interstitial Cells of Cajal Can be Injured in Acute Cholecystitis}

\section{Introduction}

Gallstones are a common health problem in developed countries. Approximately 6.5$15 \%$ of the US population suffers from gallstones at least once during their lifetime, and every year approximately $1-4 \%$ of these patients develop acute cholecystitis (AC) [1]. AC involves many factors, including gallstones and motility disorders [2]. Recent studies have shown that gallbladder motility plays a particularly important role in the pathogenesis of AC [3-5].

Interstitial cells of Cajal (ICCs) were first described about 100 years ago. ICCs exist in the digestive tract, including in the esophagus, stomach, proximal duodenum wall, small and large bowel, ileum, appendix, and colon [6]. ICCs function as smooth muscle pacemaker cells in the digestive tract where they promote gastrointestinal electrical activity. ICCs mediate and regulate gastrointestinal tract neurotransmitters and are also related to gallbladder motility regulation [7-12]. Gallbladder ICCs have also been linked to various biliary system diseases, such as gallstones and chronic cholelithiasis $[13,14]$. However, whether changes occur in gallbladder ICCs and in the stem cell factor (SCF)/c-kit pathway during AC remains unclear. The aim of this study was to explore the cellular and molecular mechanisms of gallbladder ICCs in the AC process. To address this, we examined inflammation, the morphology and density of gallbladder ICCs, apoptosis, and SCF and c-kit protein and mRNA levels.

\section{Materials and Methods}

\section{Animals and animal experiments}

Fifty adult male and female guinea pigs, weighing 250-350 g, were obtained from Wuhan Institute of Biological Products Company (Wuhan, China). The guinea pigs were maintained in standard laboratory conditions $\left(22 \pm 2^{\circ} \mathrm{C}\right.$ with a $12 \mathrm{~h}$ light/dark cycle and relative humidity of $\left.40-60 \%\right)$. The guinea pigs were provided free access to food and water. All animal experiments were approved by the Institutional Animal Care and Use Committee of Wuhan University and the animal protocols were designed to minimize pain and discomfort.

For experiments using common bile duct ligation (CBDL), guinea pigs were randomly divided into five groups, with 10 animals in each group. The five groups consisted of: a sham-administered group (control group); two groups that were intraperitoneally (IP) administered an anti-polyclonal neutrophil (PMN) antibody $24 \mathrm{~h}$ before common bile duct ligation (CBDL); and two groups of guinea pigs that were subjected to CBDL without receiving the PMN antibody. Twenty-four hours before CBDL, $0.8 \mathrm{ml}$ of rabbit anti-mouse polyclonal neutrophil serum (Anti-PMN; Cedarlane Labs, Ontario, Canada) was injected IP into each animal in the PMN groups. The CBDL $24 \mathrm{~h}$ and $48 \mathrm{~h}$ groups were not injected with anti-PMN antibodies. The shamoperated group was used as the healthy control group. Animals in the CBDL, CBDL $24 \mathrm{~h}$, and PMN CBDL $24 \mathrm{~h}$ groups were kept for $24 \mathrm{~h}$ after surgery, and those in the CBDL $48 \mathrm{~h}$ group and PMN CBDL $48 \mathrm{~h}$ group were kept for $48 \mathrm{~h}$ after surgery. After the corresponding time period, the guinea pigs in the CBDL and PMN CBDL groups underwent laparotomy and cholecystectomy $[15,16]$.

Hematoxylin-eosin staining of guinea pig gallbladder specimens was performed to detect the degree of AC. Specimens were observed using a using light microscope (Olympus BX53, Tokyo, Japan).

Histologic inflammation scores were obtained from the hematoxylin-eosin-stained gallbladder specimens. The inflammatory infiltrate was assigned a score of $0,1,2$, or 3 , representing no, mild, moderate, and severe inflammation, respectively. The approximate percentages of various cell types, including neutrophils, lymphocytes, eosinophils, histiocytes, and plasma cells, and the layers in which they were identified (i.e. the mucosa, muscle, or serosa) were noted. Hemorrhage, edema, surface ulceration, and fibroblast proliferation were assigned scores of $0,1,2$, and 3, representing no, mild, moderate, and severe conditions, respectively. The presence or absence of vascular dilation and Rokitansky-Aschoff sinus formation were noted and given a score of 1 if present and 0 if absent. Scores were summed to yield a total inflammation score between 0 and 17 [17]. 


\section{Cellular Physiology Cell Physiol Biochem 2018;47:535-544 and Biochemistry Published online: May 24, $2018 \quad$\begin{tabular}{l|l} 
DOI: 10.1159/000489987 2018 The Author(s). Published by S. Karger AG, Basel \\
www.karger.com/cpb
\end{tabular}}

Huang et al.: Interstitial Cells of Cajal Can be Injured in Acute Cholecystitis

\section{Immunohistochemistry}

Paraffin sections were evaluated by immunohistochemistry using a microwave-based antigen retrieval technique. The gallbladder mucosa and submucosa were peeled away, without affecting the muscular layer. Gallbladder specimens were fixed in 4\% polyformaldehyde solution and embedded in paraffin. Sections from paraffin-embedded gallbladder tissues were cut into 5 - $\mu \mathrm{m}$-thick slices and mounted on positively charged slides. The sections were identified using a rat monoclonal antibody against CD117/c-kit (eBioscience, San Diego, CA, USA). The specimens were incubated at room temperature for $24 \mathrm{~h}$, followed by incubation with appropriate secondary antibodies. The sections were then stained with diaminobenzidine, counterstained with hematoxylin, and observed using a light microscope (Olympus BX53). Images of CD117/c-kit-positive cells were taken for 5 randomly chosen fields ( $\times 400$ magnification) per section. The density of CD117/C-kitpositive cells was assessed using Image-Pro plus 6.0 (Media Cyber-netics, Bethesda, MD, USA).

\section{ICC apoptosis detection}

A TUNEL assay (In Situ Cell Death Detection Kit, Fluorescein, Roche Applied Science, Mannheim, Germany) was used to measure gallbladder ICC death in all groups. The TUNEL assay was performed according to the manufacturer's instructions. Images were captured using a light microscope (Olympus BX53). The density of CD117/C-kit-positive cells was assessed using Image-Pro plus 6.0 (Media Cybernetics).

\section{Protein extraction and western blot analyses}

Proteins were extracted guinea pig gallbladder muscular layer tissues (150 mg) using RIPA lysis buffer (Boster, Wuhan, China). Proteins were separated by electrophoresis using 10\% SDS polyacrylamide gels, and transferred to a nitrocellulose membrane (Pierce Biotechnology, Inc., Rockford, IL, USA). The membrane was incubated with $5 \%$ skim milk at room temperature for $2 \mathrm{~h}$ to block nonspecific binding. Samples were incubated with the primary antibody, anti-c-kit (eBioscience, San Diego, USA) or anti-SCF (Abcam, Cambridge, UK), overnight at $4^{\circ} \mathrm{C}$. The membrane was wash 3 times in TBST for $10 \mathrm{~min}$, and horseradish peroxidaseconjugated secondary antibody applied for $1 \mathrm{~h}$ at room temperature. Specific protein bands were visualized with X-ray film (Kadok China Investment Co. Ltd., Xiamen, China) using a chemiluminescence detection kit (ECL; Amersham, Pittsburgh, PA, USA). The optical density of the bands was analyzed using Alpha Innotech (Alpha Innotech Co., San Leandro, CA, USA).

\section{RNA extraction}

For each experimental group, a total of $150 \mathrm{mg}$ of gallbladder muscular layer tissues, obtained from a single guinea pig, was used for RNA extraction. Total RNA was extracted with TRIzol reagent (Invitrogen, Carlsbad, CA, USA), and RNA extraction was performed following the manufacturer's instructions.

\section{RT-PCR analysis}

cDNA was reverse-transcribed from $4.885 \mu \mathrm{g}$ of total RNA and amplified for 40 cycles of denaturation $\left(2 \mathrm{~min}\right.$ at $50^{\circ} \mathrm{C}, 10 \mathrm{~min}$ at $\left.95^{\circ} \mathrm{C}\right)$, annealing $\left(30 \mathrm{~s}\right.$ at $\left.95^{\circ} \mathrm{C}\right)$, and synthesis $\left(30 \mathrm{~s}\right.$ at $\left.60^{\circ} \mathrm{C}\right)$. The primers for GAPDH were 5'-ATCACTGCCACCCAGAAGACT-3' (forward) and 5'-CAGATCCACAACCGACACATTA-3' (reverse), generating a product of $195 \mathrm{bp}$. The primers for $S C F$ were $5^{\prime}$-GAAAGATTCCAGAGTCAGTGTCA-3' (forward) and 5'-AAGCAAAGCCAATCACAAGAG-3' (reverse), generating a product of $179 \mathrm{bp}$. The primers for $c$-kit were $5^{\prime}$-TATCCTCCTTACTCATGGTCGAA-3' (forward) and 5'-CGGGCATTTCCTTTAACCACATA-3' (reverse), generating a product of $99 \mathrm{bp}$. Subsequently, PCR products were separated by electrophoresis with size markers on a $1.5 \%$ agarose gel stained with ethidium bromide. GAPDH gene expression was used as an internal control. The relative mRNA expression values were obtained by calculating the ratio of the $S C F / c-k i t$ to $G A P D H$ amplification products.

\section{Statistical analyses}

All statistical analyses were performed using SPSS for Windows version 17.0 (SPSS, Chicago, IL, USA). Continuous variables are presented as mean \pm standard deviation (SD). Comparisons of continuous variables were performed using $t$-tests. Comparisons of categorical variables were performed using ANOVA. A two-sided $P$-value of $<0.05$ was regarded as statistically significant. 


\section{Cellular Physiology Cell Physiol Biochem 2018;47:535-544 and Biochemistry Published online: May 24, $2018 \quad$\begin{tabular}{l|l} 
DOI: 10.1159/000489987 & $\begin{array}{l}\text { (c) } 2018 \text { The Author(s). Published by S. Karger AG, Basel } \\
\text { www.karger.com/cpb }\end{array}$
\end{tabular}}

\section{Results}

\section{Evaluation of the animal model}

No guinea pigs died in the control, CBDL $24 \mathrm{~h}$, or PMN CBDL $24 \mathrm{~h}$ groups. Two guinea pigs died in the CBDL $48 \mathrm{~h}$ group, and three animals died in the PMN CBDL $48 \mathrm{~h}$ group. The mortality rates were $20 \%$ and $30 \%$, for the CBDL $48 \mathrm{~h}$ and PMN CBDL $48 \mathrm{~h}$ groups, respectively. The deaths were caused by cholecystic duct obstruction and gallbladder rupture.

Histopathological analyses revealed that the gallbladder tissue was complete, and without obvious inflammatory cell infiltration in the control group. Gallbladder tissue exhibited edema, blood expanded hyperemia, and inflammatory cell infiltration in the CBDL $24 \mathrm{~h}$ group. These features were also observed in the PMN CBDL $24 \mathrm{~h}$ group, but they were less severe than observed in the CBDL 24 h group. Additionally, in the CBDL $48 \mathrm{~h}$ group, gallbladder tissue exhibited edema and hyperplasia of fibroblasts, hyperemia and hemorrhage, and a large number of inflammatory cells, particularly neutrophils, in the mucosa and muscularis. These features, while present in the PMN CBDL $48 \mathrm{~h}$ group, were less severe than in the CBDL $48 \mathrm{~h}$ group (Fig. 1).

The histological inflammation scores for the control, CBDL $24 \mathrm{~h}$, PMN CBDL $24 \mathrm{~h}$, CBDL $48 \mathrm{~h}$, and PMN CBDL $48 \mathrm{~h}$ groups were $1.5000 \pm 0.54772,5.5000 \pm 0.54772,4.1667$ $\pm 0.40825,7.5000 \pm 0.54772$, and 5.5000 \pm 0.54772 , respectively $(F=107.317, P<$ 0.01 ). The histological inflammation scores of the PMN CBDL $24 \mathrm{~h}$ and PMN CBDL $48 \mathrm{~h}$ groups were lower than those of the CBDL $24 \mathrm{~h}$ and CBDL $48 \mathrm{~h}$ groups $(P<0.01$ for each comparison) (Fig. 2).

Taken together, these results suggest that CBDL may induce AC in guinea pigs, and that inflammation severity can be reduced by PMN.

\section{Immunohistochemical observations}

We used an anti-c-kit antibody to identify ICCs by immunohistochemistry. ICCs were predominantly fusiform in shape, with several slender lateral branches in the gallbladders of the control and experimental groups. Moreover, ICCs were predominantly located in the muscular layer, and most were within the muscularis propria and parallel to smooth muscle cells. Each ICC

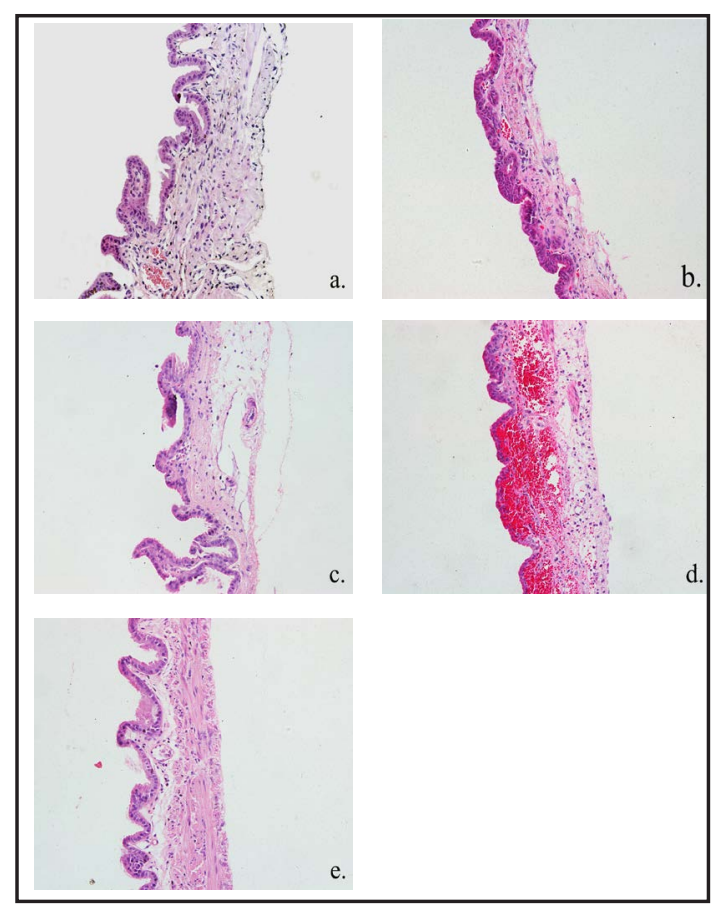

Fig. 1. Hematoxylin-eosin staining (200x) Gallbladder tissue was complete, without obvious inflammatory cell infiltration in the control group (a). Gallbladder tissue exhibited edema, blood expanded hyperemia, and inflammatory cell infiltration in the CBDL $24 \mathrm{~h}$ group (b), and these features were less severe in the PMN CBDL 24 h group (c) than in the CBDL $24 \mathrm{~h}$ group. In the CBDL $48 \mathrm{~h}$ group (d), gallbladder tissue exhibited edema and hyperplasia of fibroblasts, hyperemia and hemorrhage, and a large number of inflammatory cells, particularly neutrophils, in the mucosa and muscularis, and these features were less severe in the PMN CBDL 48 $\mathrm{h}$ group (e) than in the CBDL $48 \mathrm{~h}$ group.

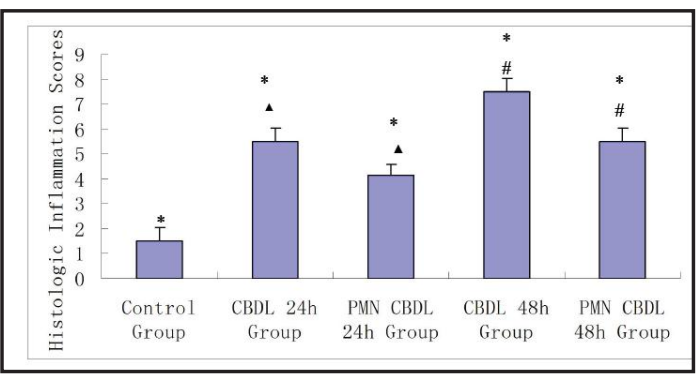

Fig. 2. Histologic Inflammation Scores for Gallbladder SpecimenThe histological inflammation scores for the PMN CBDL $24 \mathrm{~h}$ group and PMN CBDL $48 \mathrm{~h}$ group were lower than those of the CBDL $24 \mathrm{~h}$ group and CBDL 48 h group. 


\section{Cellular Physiology Cell Physiol Biochem 2018;47:535-544 \begin{tabular}{l|l} 
DOI: 10.1159/000489987 & Ond Biochemistry 2018 The Author(s). Published by S. Karger AG, Basel \\
www.karger.com/cpb
\end{tabular}

had two to five long synapses. The synapses were distributed throughout the wall of the gallbladder and were connected to form a net-like structure. Additionally, ICCs typically appeared individually or in small clusters of two to three cells. Mast cells were individual and round, and were distributed around the ICCs. No differences in the shape, size, and morphology of ICCs were observed among the different treatment groups (Fig. 3).

The number of ICCs in the control group was significantly greater than the number of ICCs in the experimental groups. Additionally, there were more ICCs in the PMN CBDL $24 \mathrm{~h}$ and PMN CBDL $48 \mathrm{~h}$ groups than there were in the CBDL $24 \mathrm{~h}$ and CBDL $48 \mathrm{~h}$ groups. The ICC counts in the control, CBDL $24 \mathrm{~h}$, PMN CBDL $24 \mathrm{~h}$, CBDL $48 \mathrm{~h}$ group, and PMN CBDL $48 \mathrm{~h}$ groups were $66.0000 \pm 2.00000,52.0000 \pm 1.73205$, $59.6667 \pm 3.05505,39.0000 \pm 1.00000$, $46.3333 \pm 0.57735(F=96.387, P<0.01)$ (Fig. 4).

Taken together, these results show that $\mathrm{AC}$ is associated with a reduced density of gallbladder ICCs, and that ICC counts are recovered after the severity of inflammation is reduced.

\section{TUNEL assays}

Our TUNEL assay results showed that the rates of gallbladder ICC apoptosis were significantly greater in the experimental groups than in the control group. ICC apoptosis rates in the control, CBDL 24 h, PMN CBDL $24 \mathrm{~h}$, CBDL $48 \mathrm{~h}$, and PMN CBDL 48 h groups were $13.6667 \pm 2.08167$, $26.3333 \pm 0.57735,22.3333 \pm 1.52753$, $28.0000 \pm 2.00000$, and $23.0000 \pm 1.00000$, respectively $(F=15.414, P<0.01)$. The level of ICC apoptosis was higher in the CDBL $24 \mathrm{~h}$ and CDBL $48 \mathrm{~h}$ groups than in their corresponding PMN CDBL $24 \mathrm{~h}$, and PMN CDBL $48 \mathrm{~h}$ experimental groups, respectively $(P<0.01$ for each, Fig. 5$)$.

The TUNEL assay results strongly suggest that gallbladder ICCs are injured during $\mathrm{AC}$ and are recovered after inflammation is reduced.

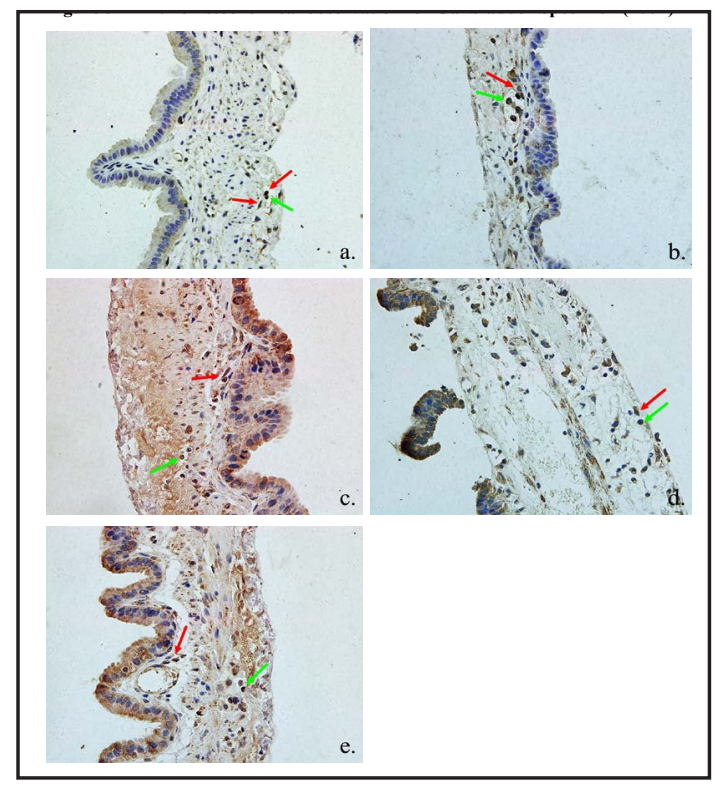

Fig. 3. Immunohistochemical observation for Gallbladder Specimen (400×)ICCs (green arrows) were predominantly fusiform in shape, with several slender lateral branches in the gallbladders of both the control group (a) and experimental groups (b. CBDL 24h Group, c. PMN CBDL 24h Group, d. CBDL 48h Group, e. PMN CBDL 48h Group). ICCs were predominantly located in the muscular layer, and most were within the muscularis propria and parallel to smooth muscle cells. ICC surfaces were c-kit-positive. Each ICC had 2-5 long synapses. They were distributed throughout the wall of the gallbladder and were connected to form a net-like structure. ICCs typically appeared individually or in small clusters of two to three cells. Mast cells (red arrows) were individual and round, and were distributed around the ICCs.

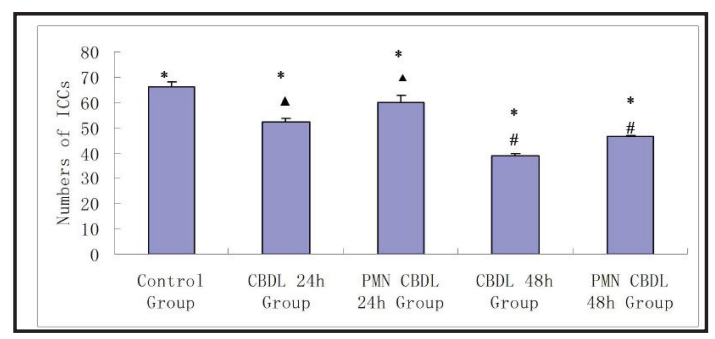

Fig. 4. Numbers of ICCs in different groupsThe number of ICCs in the control group was significantly greater than those in experimental groups. There were more ICCs in the PMN CBDL $24 \mathrm{~h}$ group and PMN CBDL 48 h group than in the CBDL 24 h group and CBDL 48 h group.

\section{SCF and c-kit protein expression}

Based on western blot analyses, the expression levels both of c-kit and SCF were significantly lower in the experimental groups than in the control group. SCF and c-kit protein 


\section{Cellular Physiology Cell Physiol Biochem 2018;47:535-544 \begin{tabular}{ll|l} 
and Biochemistry & $\begin{array}{l}\text { DOI: 10.1159/000489987 } \\
\text { Published online: May 24, } 2018\end{array}$ & $\begin{array}{l}\text { C } 2018 \text { The Author(s). Published by S. Karger AG, Basel } \\
\text { www.karger.com/cpb }\end{array}$
\end{tabular}

expression levels were lower in the CBDL $48 \mathrm{~h}$ group than in the CBDL $24 \mathrm{~h}$ group, and were also lower in the CBDL $24 \mathrm{~h}$ and CBDL $48 \mathrm{~h}$ groups than in the PMN CBDL $24 \mathrm{~h}$ group and PMN CBDL 48 h group, respectively. The ratios of SCF to $\beta$-actin in the control, CBDL $24 \mathrm{~h}$, PMN CBDL $24 \mathrm{~h}$, CBDL $48 \mathrm{~h}$, and PMN CBDL $48 \mathrm{~h}$ groups, were $0.6907 \pm 0.15970,0.4887 \pm$ $0.12889,0.5560 \pm 0.10828,0.2587 \pm 0.05750$, and $0.3340 \pm 0.06500$, respectively $(F=7.532$, $P<0.01)$. The ratios of c-kit to $\beta$-actin were $0.6170 \pm 0.19919,0.4813 \pm 0.12396,0.5107$ $\pm 0.13887,0.2383 \pm 0.05654$, and $0.2663 \pm$ 0.07071 , respectively $(F=4.861, P<0.05)$ (Fig. 6).

Taken together, these results show that SCF and c-kit protein expression decreased in $\mathrm{AC}$ and increased after the resolution of inflammation.

\section{SCF and c-kit mRNA expression}

RT-PCR analyses revealed thatSCFand $c$-kit mRNA levels were lower in all experimental groups than in the control group. The mRNA levels of $S C F$ and $c$-kit were much lower in the CBDL $48 \mathrm{~h}$ group than in the CBDL $24 \mathrm{~h}$ group. $S C F$ and $c$-kit expression levels in the CBDL $24 \mathrm{~h}$ and CBDL $48 \mathrm{~h}$ groups were lower than those in the PMN CBDL $24 \mathrm{~h}$ and PMN CBDL $48 \mathrm{~h}$ groups. The relative expression levels of $S C F$ and c-kit were compared to the control group, which was set as 1.0. In the CBDL 24 h, PMN CBDL $24 \mathrm{~h}$, CBDL $48 \mathrm{~h}$, and PMN CBDL $48 \mathrm{~h}$ groups, relative SCF expression levels were $0.6450 \pm 0.01967,0.8350 \pm 0.04657$, $0.3477 \pm 0.04216$, and $0.5220 \pm 0.16664$, respectively. In the CBDL $24 \mathrm{~h}$, PMN CBDL 24 h, CBDL $48 \mathrm{~h}$, and PMN CBDL $48 \mathrm{~h}$ groups, relative $c$-kit expression levels were $0.7510 \pm$ $0.07750,0.8287 \pm 0.10005,0.4447 \pm 0.10441$, and $0.5503 \pm 0.05877$. The F-values were calculated as 30.670 and 24.154 , for $S C F$ and $c$-kit respectively, and all $P$ values were less than 0.05 (Fig. 7).

The RT-PCR results support those obtained by immunohistochemistry, TUNEL detection, and western blotting. SCF and $c$-kit mRNA expression levels decreased during acute inflammation and recovered after inflammation was resolved.

\section{Discussion}

$\mathrm{AC}$ is an acute inflammatory disease of the gallbladder and is often associated with gallbladder motility disorder $[3,4]$. AC is a common diagnosis in internal medicine and

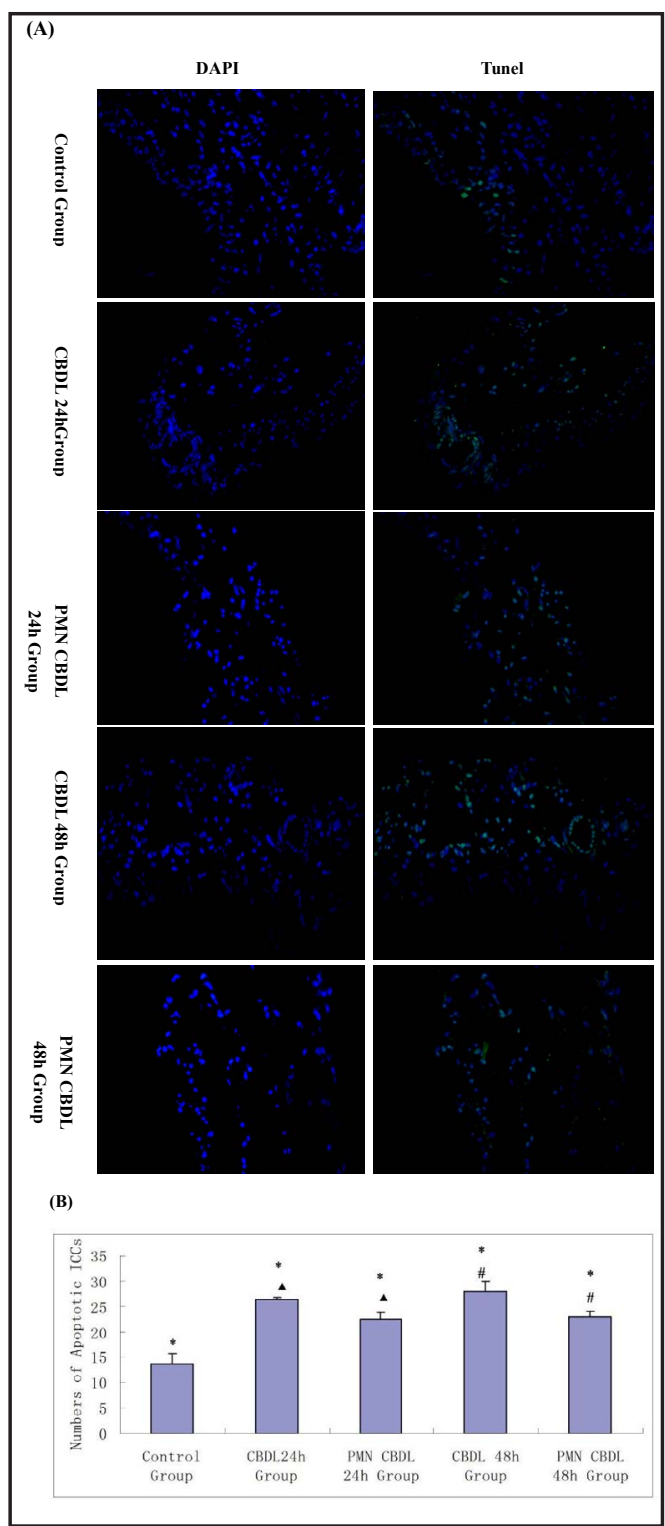

Fig. 5. TUNEL Detection $(400 \times)$ In the experimental groups, the rates of gallbladder ICC apoptosis were significantly greater than that of the control group. The rate of ICC death was higher in the CDBL $24 \mathrm{~h}$ group than in the PMN CDBL $24 \mathrm{~h}$ group, and higher in the CDBL $48 \mathrm{~h}$ group than in the PMN CDBL 48 h group. 
Fig. 6. SCF and c-kit protein expression in different groupsThe protein expression levels both of c-kit and SCF were significantly lower in the experimental groups than in the control group (a). SCF and c-kit protein expression levels were lower in the CBDL $48 \mathrm{~h}$ group (d) than in the CBDL $24 \mathrm{~h}$ group (b), and were lower in the CBDL $24 \mathrm{~h}$ group and CBDL $48 \mathrm{~h}$ group than in the PMN CBDL $24 \mathrm{~h}$ group (c) and PMN CBDL 48 h group (e), respectively.

$\mathrm{F}=7.532, \mathrm{P}<0.01$

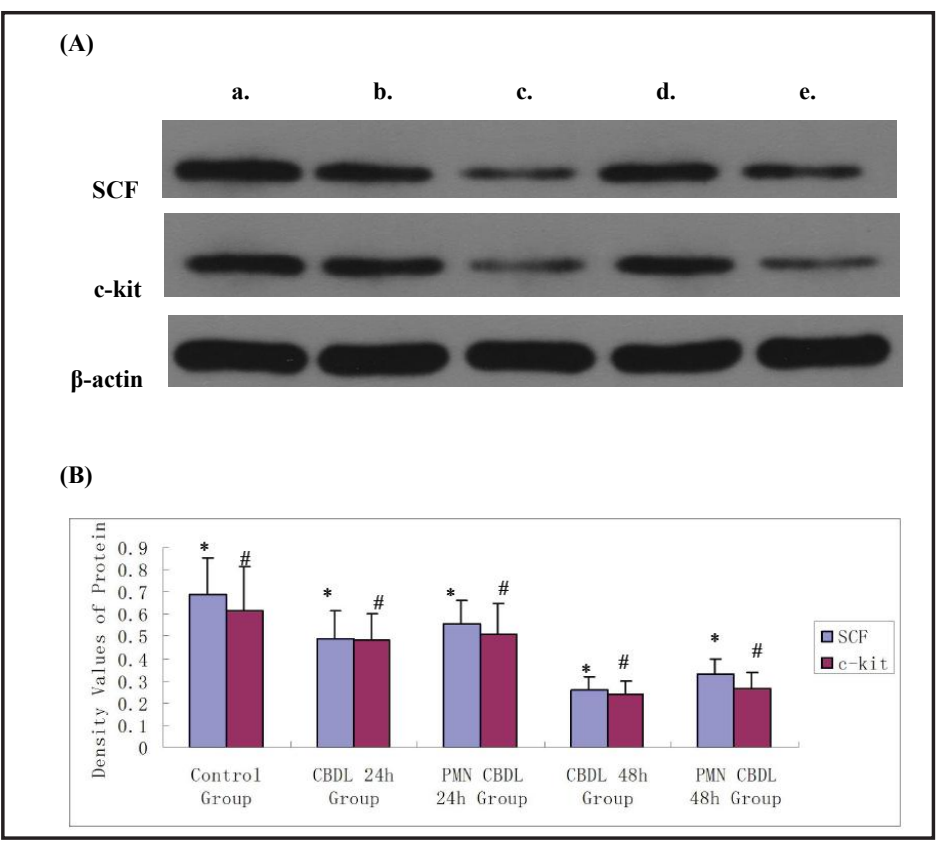

Fig. 7. mRNA expression of SCF and c-kit in different groupsSCF and c-kit mRNA levels were lower in all experimental groups than in the control group (a). In the CBDL $48 \mathrm{~h}$ group (d), SCF and c-kit mRNA levels were much lower than those in the CBDL 24 h group (b). Expression levels in the CBDL $24 \mathrm{~h}$ group and CBDL $48 \mathrm{~h}$ group were lower than those in the PMN CBDL 24 h group (c) and PMN CBDL $48 \mathrm{~h}$ group (e).

$* \mathrm{~F}=30.670, \mathrm{P}<0.05$

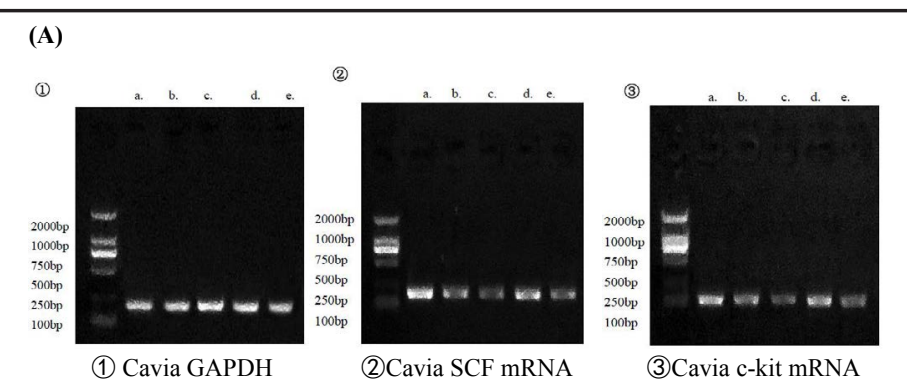

(B)

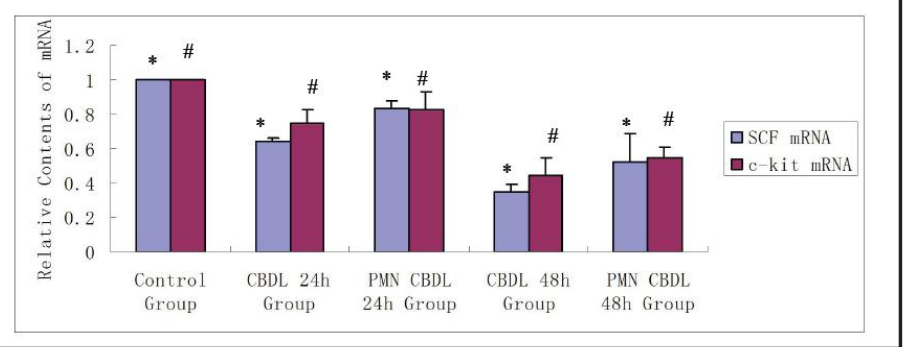

surgery departments, but heterogeneity in its clinical presentation makes diagnosis and management difficult [2].

ICCs were first described in detail in the gastrointestinal tract by Santiago Ramo'n y Cajal in 1893 [18, 19], and they express the specific marker, c-kit [20]. ICCs in the gastrointestinal tract are the pacemaker cells of gut motility and are related to motility disorders [21]. Recent studies have shown that reduced biliary system ICCs, ICC injury or loss of function, and compromises in the and c-kit/SCF pathway may play important roles in biliary system motility diseases, including cholelithiasis $[16,17]$ and may be closely connected to malignant tumors in the biliary system. Indeed, numerous CD117- positive cells (c-kit protein) have been detected in pathological gallbladder malignant stromal tumor specimens [22].

ICCs are found in the biliary systems of both guinea pigs and humans [23, 24]. Gallbladder motility involves various regulatory mechanisms, such as gallbladder smooth 


\section{Cellular Physiology Cell Physiol Biochem 2018;47:535-544 \begin{tabular}{c|c|c|} 
DOI: 10.1159/000489987 & O 2018 The Author(s). Published by S. Karger AG, Basel \\
wwww.karger.com/cpb
\end{tabular} \\ Huang et al.: Interstitial Cells of Cajal Can be Injured in Acute Cholecystitis}

muscle and nervous circuit activity, including gallbladder ICCs. In particular, gallbladder ICCs may be related to AC. Gallbladder ICCs exhibit damage and/or reduced numbers in almost every gastrointestinal motility disorder, and abnormalities in motor activity lead to impaired regional transit and symptoms. However, it is not clear whether ICCs are repaired after disease recovery $[25,26]$. Recent studies have indicated that ICCs in the biliary system play a major role in initiating pacemaker activity to adjust gallbladder movement, and that their dysfunction is closely related to a variety of gallbladder motility disorders $[27,28]$. Moreover, it has been shown that ICCs undergo apoptosis over time, and that ICC regeneration is required for the maintenance of normal ICC networks in healthy tissues [29]. Furthermore, menthol-induced membrane potential depolarizations, that occur in G-protein, $\mathrm{Ca}^{2+}$ pathways via TRPA1 M2 and M3 receptors, were shown to be involved in this process [30, 31]. Various factors, including regional obstruction and subsequent proximal dilation, and nervous system and immune system injury can lead to ICC damage and loss [26]. In AC, biliary tract obstruction leads to ICC injury in the gallbladder. This then blocks c-kit receptors, and results in gallbladder ICC loss, increased ICC apoptosis, and a lack of regeneration and maintenance of ICC networks [32,33]. c-kit receptors modulate the generation and rhythmicity of electrical activity to regulate the excitability of gallbladder smooth muscle cells [27]. Recent studies have also shown that when c-kit receptors are blocked, ICCs disappear [34].

Neutrophils are key cells in acute inflammation [25]. In our study, a substantial number of neutrophils infiltrated the gallbladder mucosa and muscularis during AC. Treatment with an anti-PMN antibody reduced neutrophil counts, and reduced and blocked neutrophil infiltration and superoxide dismutase exosmosis to reduce the inflammatory response [25]. After IP injection of anti-PMN, the severity of gallbladder tissue inflammation and the histologic inflammation score were reduced. c-kit receptors return to normal when AC is relieved, resulting in the repair and recovery of gallbladder ICCs. However, additional studies are required to delineate the underlying mechanisms.

ICCs regulate gallbladder motility and mediate neurotransmission from enteric motor neurons [35]. The tyrosine kinase receptor, c-kit, and its ligand, SCF, are important for the normal development, maturation, and phenotypic maintenance of ICCs [36, 37]. The blocking of c-kit receptors during $\mathrm{AC}$, resulted in a significant decrease in the expression of c-kit and SCF at both the mRNA and protein levels [38]. After inflammation was relieved, c-kit receptors returned to normal, and the SCF/c-kit pathway was upregulated. Changes in SCF/ c-kit protein and mRNA expression in AC suggest that they are involved in the impairment and repair of gallbladder ICCs and disease development [39]. These results provide a basis for the development of ICC-based replacement therapies for AC with gallbladder motility disorder [40].

In summary, our results indicate that $\mathrm{AC}$ causes a reduction in ICC number, increased ICC apoptosis, and reduced SCF and c-kit expression. After the resolution of inflammation, we observed ICC recovery and the recovery of SCF and c-kit expression. These changes may be related to ICC function and AC in patients with gallbladder motility disorder.

\section{Acknowledgements}

This study was supported by the National Natural Science Foundation of China (NSFC) (NO. 81170351) and the Xi'an Medical University Doctor Scientific Research Foundation Project (No. 2017 DOC 04).

\section{Disclosure Statement}

No conflict of interests exists. 


\section{Cellular Physiology Cell Physiol Biochem 2018;47:535-544 \begin{tabular}{l|l} 
and Biochemistry Published online: May 24, 2018 & $\begin{array}{l}\text { (c) } 2018 \text { The Author(s). Published by S. Karger AG, Basel } \\
\text { www.karger.com/cpb }\end{array}$
\end{tabular}}

Huang et al.: Interstitial Cells of Cajal Can be Injured in Acute Cholecystitis

\section{References}

1 Sert İ, İpekci F, Engin Ö, Karaoğlan M, Çetindağ Ö: Outcomes of early cholecystectomy (within 7 days of admission) for acute cholecystitis according to diagnosis and severity grading by Tokyo 2013 Guideline. Turk J Surg 2017;33:80-86.

-2 Ambe PC, Papadakis M, Zirngibl H: A proposal for a preoperative clinical scoring system for acute cholecystitis. J Surg Res 2016;200:473-479.

-3 Kimura Y, Takada T, Kawarada Y, Nimura Y, Hirata K, Sekimoto M, Yoshida M, Mayumi T, Wada K, Miura F, Yasuda H, Yamashita Y, Nagino M, Hirota M, Tanaka A, Tsuyuguchi T, Strasberg SM, Gadacz TR: Definitions, pathophysiology, and epidemiology of acute cholangitis and cholecystitis: Tokyo Guidelines. J Hepatobiliary Pancreat Surg 2007;14:15-26.

4 Parkman HP, Bogar LJ, Bartula LL, Pagano AP, Thomas RM, Myers SI: Effect of experimental acalculous cholecystitis on gallbladder smooth muscle contractility. Dig Dis Sci 1999;44:2235-2243.

5 Wilkins T, Agabin E, Varghese J, Talukder A: Gallbladder Dysfunction: Cholecystitis, Choledocholithiasis, Cholangitis, and Biliary Dyskinesia. Prim Care 2017;44:575-597.

6 Pasternak A, Szura M, Gil K, Matyja A: Interstitial cells of Cajal - systematic review. Folia Morphol (Warsz) 2016;75:281-286.

7 Al-Shboul OA: The importance of interstitial cells of cajal in the gastrointestinal tract. Saudi J Gastroenterol 2013;19:3-15.

-8 Sanders KM, Ward SM, Koh SD: Interstitial cells: regulators of smooth muscle function. Physiol Rev 2014;94:859-907.

-9 Abramovic M, Radenkovic G, Velickov A: Appearance of interstitial cells of Cajal in the human midgut. Cell Tissue Res 2014;356:9-14.

-10 Lies B, Gil V, Groneberg D, Groneberg D, Seidler B, Saur D, Wischmeyer E, Jiménez M, Friebe A: Interstitial cells of Cajal mediate nitrergic inhibitory neurotransmission in the murine gastrointestinal tract. Am J Physiol Gastrointest Liver Physiol 2014;307:G98-G106.

11 Huizinga JD, Chen JH, Mikkelsen HB: Interstitial cells of Cajal, from structure to function. Front Neurosci 2013;7:43.

12 Huizinga JD, Chen JH: Interstitial cells of Cajal: update on basic and clinical science. Curr Gastroenterol Rep 2014;16:363.

13 Villanacci V, Del Sordo R, Salemme M, Cadei M, Sidoni A, Bassotti G: The enteric nervous system in patients with calculous and acalculous gallbladder. Dig Liver Dis 2016;48:792-795.

14 Feng H, Wang F, Wang C: C-Kit expression in the gallbladder of guinea pig with chronic calculous cholecystitis and the effect of Artemisia capillaris Thunb on interstitial cells of Cajal. Iran J Basic Med Sci 2016;19:720-725.

15 Tag CG, Sauer-Lehnen S, Weiskirchen S, Borkham-Kamphorst E, Tolba RH, Tacke F, Weiskirchen R: Bile Duct Ligation in Mice: Induction of Inflammatory Liver Injury and Fibrosis by Obstructive Cholestasis. J Vis Exp 2015, 96:1-11.

-16 Tag CG, Weiskirchen S, Hittatiya K, Tacke F, Tolba RH Weiskirchen R: Induction of experimental obstructive cholestasis in mice. Lab Anim 2015;49:70-80.

-17 Parkman HP, Bogar LJ, Bartula LL, Pagano AP, Thomas RM, Myers SI: Effect of experimental acalculous cholecystitis on gallbladder smooth muscle contractility. Dig Dis Sci 1999;44:2235-2243.

18 Sanders KM, Ward SM: Interstitial cells of Cajal: a new perspective on smooth muscle function. J Physiol 2006;576:721-726.

19 Thuneberg L: One hundred years of interstitial cells of Cajal. Microsc Res Tech 1999;47:223-238.

20 Huang Y, Mei F, Yu B, Zhang HJ, Han J, Jiang ZY, Zhou DS: Distribution of the interstitial Cajal-like cells in the gallbladder and extrahepatic biliary duct of the guinea-pig. Acta histochemica 2009;111:157-165.

21 Wei R, Parsons SP, Huizinga JD: Network properties of interstitial cells of Cajal affect intestinal pacemaker activity and motor patterns, according to a mathematical model of weakly coupled oscillators. Exp Physiol 2017;102:329-346.

22 Padhi S, Nayak HK: Primary Extragastrointestinal Stromal Tumours in the Hepatobiliary Tree and Telocytes. Adv Exp Med Biol 2016;913:207-228. 


\section{Cellular Physiology Cell Physiol Biochem 2018;47:535-544 \begin{tabular}{lll} 
DOI: 10.1159/000489987 & and Biochemistry & $\begin{array}{l}\text { O 2018 The Author(s). Published by S. Karger AG, Basel } \\
\text { www.karger.com/cpb }\end{array}$ \\
\cline { 2 - 3 }
\end{tabular}}

Huang et al.: Interstitial Cells of Cajal Can be Injured in Acute Cholecystitis

23 Hinescu ME, Ardeleanu C, Gherghiceanu M, Popescu LM: Interstitial Cajal-like cells in human gallbladder. J Mol Histol 2007;38:275-284.

-24 Ahmadi O, Nicholson Mde L, Gould ML, Mitchell A, Stringer MD: Interstitial cells of Cajal are present in human extrahepatic bile ducts. J Gastroenterol Hepatol 2010;25:277-285.

-25 Riera NE, Rosso Saltó M, Galán V, Canalejo K, Khoury M, Aixalá M, Kantor GL, Vermeulen M, Bengió R, De Bracco MM: Anti-polymorphonuclear neutrophil antibodies in patients with leukopenia or neutropenia. Int J Lab Hematol 2010;32:e96-e105.

26 Huizinga JD, Zarate N, Farrugia G: Physiology, injury and recovery of interstitial cells of Cajal: basic and clinical science. Gastroenterology 2009;137:1548-1556.

-27 Lavoie B, Balemba OB, Nelson MT, Ward SM, Mawe GM: Morphological and physiological evidence for interstitial cell of Cajal-like cells in the guinea pig gallbladder. J Physiol 2007;579:487-501.

28 Fan Y, Wu S, Fu B, Weng C, Wang X: The role of interstitial Cajal-like cells in the formation of cholesterol stones in guinea pig gallbladder. Hepatol Int 2015;9: 612-620.

29 Gibbons SJ, De Giorgio R, Faussone Pellegrini MS, Garrity-Park MM, Miller SM, Schmalz PF, Young-Fadok TM, Larson DW, Dozois EJ, Camilleri M, Stanghellini V, Szurszewski JH, Farrugia G: Apoptotic Cell Death of Human Interstitial Cells of Cajal. Neurogastroenterol Motil 2009;21:85-93.

-30 Kim HJ, Han T, Kim YT, So I, Kim BJ: Magnolia Officinalis Bark Extract Induces Depolarization of Pacemaker Potentials Through M2 and M3 Muscarinic Receptors in Cultured Murine Small Intestine Interstitial Cells of Cajal. Cell Physiol Biochem 2017;43:1790-1802.

-31 Kim HJ, Wie J, So I, Jung MH, Ha KT, Kim BJ: Menthol Modulates Pacemaker Potentials through TRPA1 Channels in Cultured Interstitial Cells of Cajal from Murine Small Intestine. Cell Physiol Biochem 2016;38:1869-1882.

-32 Huang ZP, Qiu H, Yang Y, Zhang L, Yang B, Lin MJ, Yu BP: The Role of Interstitial Cells of Cajal in Acute Cholecystitis in Guinea Pig Gallbladder. Cell Physiol Biochem 2016;38:1775-1784.

33 Huang ZP, Qiu H, Yang Y, Yu BP: Effect of Neutrophils on Gallbladder Interstitial Cajal-Like Cells in Guinea Pig Model of Acute Cholecystitis. Cell Physiol Biochem 2016;39:2033-2043.

34 Torihashi S, Nishi K, Tokutomi Y, Nishi T, Ward S, Sanders KM: Blockade of kit signaling induces transdifferentiation of interstitial cells of cajal to a smooth muscle phenotype. Gastroenterology 1999;117:140-148.

-35 Sanders KM, Ordög T, Koh SD, Torihashi S, Ward SM: Development and plasticity of interstitial cells of Cajal. Neurogastroenterol Motil 1999;11:311-338.

-36 Fan Y, Wu S, Fu B, Yan X, Wang X, Zhang W: Decreased expression of stem cell factor mRNA and protein in the gallbladders of guinea pigs fed on high cholesterol diet. Int J Clin Exp Med 2015;8:6379-6383.

37 Rich A, Miller SM, Gibbons SJ, Malysz J, Szurszewski JH, Farrugia G: Local presentation of Steel factor increases expression of c-kit immunoreactive interstitial cells of Cajal in culture. Am J Physiol Gastrointest Liver Physiol 2003;284:G313-G320.

-38 Hu WM, Luo HS, Ding XW: Expression of C-kit messenger ribonucleic acid and C-kit protein in the gallbladders in guinea pigs of high cholesterol diet. Dig Dis Sci 2009;54:1651-1655.

-39 Huizinga JD, White EJ: Progenitor cells of interstitial cells of Cajal: on the road to tissue repair. Gastroenterology 2008;134:1252-1254.

40 Zhou J, O'Connor MD, Ho V: The Potential for Gut Organoid Derived Interstitial Cells of Cajal in Replacement Therapy. Int J Mol Sci 2017;18:2059. 